\title{
Feeding combination of Lactobacillus casei and extracts of dahlia tuber or garlic on intestinal bacteria, nutrients digestibility and performance of broiler chickens
}

\author{
Istna Mangisah ${ }^{* 1,2)}$, Nyoman Suthama ${ }^{2)}$ and Heni Rizqiati ${ }^{2)}$ \\ ${ }^{1)}$ Faculty of Animal and Agricultural Sciences, Diponegoro University, J1. Prof. Soedarto \\ No.50275, Tembalang, Kec. Tembalang, Semarang, Central Java, 50275 Indonesia \\ ${ }^{2)}$ Vocational School, Diponegoro University, Jl. Prof. Soedarto No.50275, Tembalang, Kec. \\ Tembalang, Semarang, Central Java, 50275, Indonesia
}

Submitted: 19 October 2019, Accepted: 28 March 2020

\begin{abstract}
This study aimed to evaluate the effect of dietary inclusion of $2 \%$ synbiotic (Lactobacillus casei + dahlia tuber extract/LEDT or Lactobacillus casei + garlic extract/LEGT) on intestinal bacteria, nutrient digestibility, and growth of broiler chickens. A total of 150 birds of one-day-old male Cobb broiler were randomly assigned into three groups of treatment with five replications (10 birds each). Dietary treatments applied were $\mathrm{T} 0=$ basal ration, $\mathrm{T} 1=$ basal ration $+2 \%$ LEDT, T2 = basal ration $+2 \%$ LEGT. Synbiotics were given to starter chicken (from 2 to 3 weeks old). Parameters observed were intestinal bacteria (total lactic acid bacteria/LAB and coliform counts), nutrients digestibility, and body weight. Data were subjected to analysis of variance and followed by Duncan test. The results showed that the population of intestinal LAB in synbiotic-treated birds significantly $(\mathrm{P}<0.05)$ increased while coliform decreased as compared to control group. Protein and crude fiber digestibilities, and growth of broiler chickens given dietary inclusion of synbiotic either LEDT or LEGT were also significantly $(\mathrm{P}<0.05)$ higher than those fed control diet. In conclusion, dietary inclusion of $2 \%$ synbiotic LEDT increase body weight of broiler chickens through the improved balance of intestinal microbiota and nutrients digestibility.
\end{abstract}

Keywords: Synbiotic; Intestinal microbiota; Nutrient digestibility; Growth; Broiler chicken

*Corresponding Author: istnamangisah@yahoo.co.id 


\section{INTRODUCTION}

Poultry meat demand is estimated to continuously increase due to the population as the consumers of animal protein is also growing fast. The high growth rate with high meat production of broiler is considerably hope to contribute to the fulfillment of meat demand. To support such high productivity, broilers need rations with high nutrients content and balance to fulfill the requirement. The availability of nutrients for growth, especially protein, can be identified from the rate of digestibility because the higher digestibility the more nutrients that can be possibly supplied for body tissue synthesis, muscle protein in particular. The enhancement of nutrients digestibility can be achieved when supported by the healthy gastrointestinal tract (GIT). Microbiota population plays a significant role in the health of the digestive tract, digestive processes, productivity, and the possibility of disease susceptibility. The improved composition and balance of intestinal microbiota are closely related to the condition dominated by beneficial bacteria, but not pathogens. Commensal bacteria play an important role in the gut health and metabolic processes of the host, while pathogenic bacteria cause harmful effects either directly or indirectly. The condition of intestinal microbiota, either composition or balance, is influenced by kinds of feed provided (Yadav and Jha, 2019).

Therefore, the feed given to animals must support the condition of the gut and maintain the balance of intestinal microbes. The results of previous studies indicated that administration of synbiotics can improve intestinal microbiota and increase growth in chickens (Sugiharto, 2016; Fair and Magray, 2012; Abdeel-Raheem, 2012). Synbiotic is defined as a combination of probiotics and prebiotics (Huyghebaert et al., 2011). Previous studies have shown the beneficial effects of synbiotics on gut microbial ecosystems and immune function of chickens. Feeding diet added with a combination of $1.2 \%$ dahlia tuber inulin and
$1.2 \mathrm{~mL}$ Lactobacillus sp. increased jejunal villi height, protein digestibility, final body weight, and decreased jejunal coliform counts in highly selected pure native chickens (Purbarani et al., 2019). Microorganisms in Bacteria derived from synbiotic in the intestine produce substances that have bactericidal or bacteriostatic properties, which can suppress the colonization of undesirable microorganisms. This can control the balance of host intestinal microbiota from pathogenic bacteria. Synbiotic administration has been proven to be effective in increasing the growth of broilers (Abdel-Raheem et al., 2012). Prebiotics combined with probiotics cause the better growth of beneficial bacteria, which effect is due to the availability of substrate, in term of prebiotic as "source of feed," to support its growth. Bacteria, especially LAB, can ferment low molecule weight carbohydrates such as lactose, to produce short-chain fatty acids such as acetic, propionic, and butyric acids, causing the decrease in intestinal $\mathrm{pH}$ of the host. Some species also produced hydrogen peroxide that could inhibit the growth of gram-negative bacteria (Yirga, 2015; Bajagai et al., 2016). Bactericidal agent produced by LAB can penetrate the outer membrane of gram-negative bacteria and deactivate them together with others, creating an antimicrobial environment, such as low temperature, organic acid production and detergents (Alakomi et al., 2000). This condition caused a healthy digestive tract, improved intestinal morphology so that it could improve the digestive process (Awad et al., 2009). Finally, it increased the availability of nutrients for body tissue synthesis and could improve the growth performance of broiler chickens.

One of the potential bacteria that can function as probiotics is Lactobacillus casei. Probiotic from Lactobacillus casei could produce anti-microbial substances and suppressed the growth of pathogenic bacteria (Sunaryanto et al., 2014). The existence of this probiotic bacteria would be 
successfully improved when fed together with prebiotic inulin as a "source of nutrient," called as a synbiotic or just a status of combination. Inulin can be obtained from dahlia tuber and garlic bulb in the forms of either powder or extract. Dahlia tuber in the form of powder contains inulin with the range of 69.50 to $75.48 \%$. However, inulin in garlic is far lower than that in dahlia tuber namely, around 9 to $16 \%$ of fresh weight. Extraction can be carried out to obtain inulin from dahlia tuber and garlic bulb. Inulin extraction principle was to utilize the solubility of inulin in water and ethanol (Sundari et al., 2014).

The solubility of inulin that recrystallized with ethanol was greater than that recrystallized with water. At a temperature of $60^{\circ}$, the solubility of inulin that recrystallized with ethanol was $47.0 \mathrm{~g} /$ $100 \mathrm{~g}$, while that with water was $1.57 \mathrm{~g} / 100$ g (Azhar, 2009). Previous studies have shown that dahlia tuber in the forms of either powder at $1.2 \%$ or extract at $1.17 \%$ as source of prebiotic inulin reduced meat fat and cholesterol and increased body weight gain of crossbred local chickens (Fajrih et al., 2014). Similar levels and forms of dahlia inulin was also found to increase protein digestibility, SCFA production, and growth of crossbred local chickens (Fanani et al., 2016). Furthermore, Faradila et al. (2016) confirmed that feeding a combination of prebiotic inulin of dahlia tubers at $1.2 \%$ and Lactobacillus sp. at $1.2 \mathrm{ml}(108 \mathrm{cfu} / \mathrm{ml})$ decreased Escherichia coli population and intestinal $\mathrm{pH}$ but increased the amount of $\mathrm{LAB}$ and weight gain in crossbred local chicken.

There are many studies have been previously conducted using prebiotic alone or in combination with probiotic. Feeding diet added with Lactobacillus sp. alone as probiotic successfully improved chickens health and produced higher meat quality in broiler (Cholis et al., 2018; Wulandari et al., 2018). The improvement of health status and production quality and performances were also reported in crossbred local chicken when probiotic fed in combination with prebiotic (Abdurrahman et al., 2016a; 2016b). A combination of Lactobacillus acidophilus and 10,000 ppm red onion inulin were able to inhibit growth of Escherichia coli (Hartono et al., 2012).

Research on synbiotics have been previously conducted many elsewhere, but that concerning a combination of Lactobacillus casei and extracts of dahlia tuber or garlic as a synbiotic given in broiler of starter period has never been done. Therefore, the present study was conducted to evaluate the effect of dietary inclusion of synbiotics. Namely, Lactobacillus casei plus dahlia tuber extract (LEDT) compared to Lactobacillus casei plus garlic extract (LEGT) on intestinal bacterial populations, nutrients digestibility, and growth of starter broiler.

\section{MATERIALS AND METHODS Experimental Animal and Diet}

One hundred and fifty birds of 7-dayold broilers with initial body weight of $184,62 \pm 10,32 \mathrm{~g}$ were randomly placed in 15 experimental units, and given experimental diet for three weeks. The experimental diet, containing $3000 \mathrm{kcal} / \mathrm{kg}$ $\mathrm{ME}$ and $21.5 \%$ crude protein, were composed of corn, rice bran, soybean meal, meat bone meal (MBM), and premix (Table $1)$.

Synbiotics tested were combination of Lactobacillus casei and extract of dahlia tuber (LEDT) and Lactobacillus casei and extract of ginger bulb (LEGT). Synbiotic preparation was started with the extraction of dahlia tuber and garlic bulb using maceration method, with $70 \%$ alcohol, and followed by the rejuvenation of Lactobacillus casei bacteria. One dose of Lactobacillus casei isolate was inoculated in $50 \mathrm{ml}$ of $10 \%$ skim milk (10 $\mathrm{g}$ in $100 \mathrm{ml}$ of sterile distilled water), and than it was incubated for 2 x 24 hours.

Liquid culture obtained from the results of incubation were then calculated for bacterial population by the total plate count (TPC) method. $50 \mathrm{ml}$ of liquid culture of incubation result was re-inoculated in 450 
$\mathrm{ml}$ of skim milk (liquid mixture was 500 $\mathrm{ml}$ ), and then counted again with TPC. Furthermore, $500 \mathrm{ml}$ of liquid mixture was added with prebiotic sources $(2 \%)$ of sterilized dahlia tuber or garlic extracts, at a concentration of $2 \%$ and was re-incubated for $2 \times 24$ hours to produce synbiotic. The bacterial population was finally counted with TPC method (Ngatirah and Ulfah, 2013).

Table 1. Composition and nutrient contents of experimental ration

\begin{tabular}{|c|c|}
\hline Ingredient & Composition (\%) \\
\hline Maize & 44.00 \\
\hline Rice bran & 19.00 \\
\hline Soybean meal & 27.20 \\
\hline MBM & 8.5 \\
\hline $\mathrm{CaCO}_{3}$ & 0.3 \\
\hline premix $^{1}$ & 1.00 \\
\hline Total & 100 \\
\hline \multicolumn{2}{|l|}{ Nutrient contents: } \\
\hline Metabolizable energy $(\mathrm{kcal} / \mathrm{kg})^{2}$ & 3001.11 \\
\hline Crude protein $(\%)^{3}$ & 21.6 \\
\hline Crude Fiber $(\%)^{3}$ & 5.69 \\
\hline Ether extract $(\%)^{3}$ & 3.84 \\
\hline Calcium $(\%)^{3}$ & 1.12 \\
\hline Phosphorus $(\%)^{3}$ & 0.63 \\
\hline Methionine $(\%)^{4}$ & 0.42 \\
\hline Lysine $(\%)^{4}$ & 1.31 \\
\hline \multicolumn{2}{|c|}{ 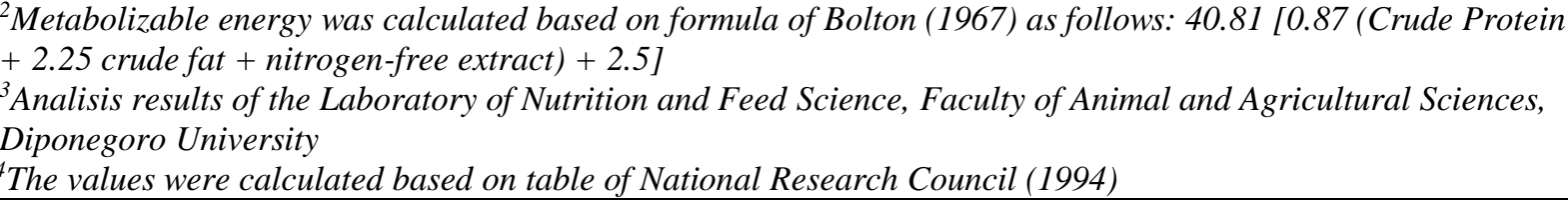 } \\
\hline
\end{tabular}

\section{Experimental Design for In vivo synbiotic test}

In vivo trial was arranged in a completely randomized design with three dietary treatments and five replications. Dietary treatments tested were as follows :

$\mathrm{T} 0=$ basal ration

$\mathrm{T} 1=$ basal ration $+2 \%$ synbiotic of LEDT

$\mathrm{T} 2=$ basal ration $+2 \%$ synbiotic of LEGT

\section{Parameters Measured}

a. Populations of lactic acid bacteria and Escherichia coli in the small intestine

One bird of 21-day old was randomly taken from each replication. The birds were then slaughtered and dissected to obtain part of the small intestine for digesta collection. Intestinal digesta samples were put into sterile bottles before laboratory analysis for total lactic acid bacteria (LAB) and Escherichia coli (E. coli) counts.
Calculation for total LAB was performed based on pour plate method using MRSA media, while that for $E$. coli was processed with TBX media. One ml diluted digesta sample was put into petri dish for preparation of either LAB or E. coli calculation. The media was poured into a 15 $\mathrm{ml}$ petri dish, then covered and placed on the shaking table to form number eight and left frozen. Solid samples were incubated in a reverse incubator for 48 hours at $44^{\circ} \mathrm{C}$ for $\mathrm{LAB}$ and $37^{\circ} \mathrm{C}$ for E. coli. After the incubation period was complete, the number of colonies formed was calculated by using the Quebec colony counters.

b. Nutrient Digestibility and Body Weight

Digestibility trial was performed using total collection method, and excreta was collected from day 21 to day 24. Excreta was then dried and analyzed for crude protein and crude fiber. Feed intake was recorded 
during excreta collection to calculate nutrients consumption subtracted by fecal nutrients excretion. Nutrient, protein and crude fiber, digestibility is was measured according to Meluzi et al. (2001), and Kong and Adeola (2014), respectively, as follows:

$$
\text { Nutrient digestibility }=\left[\frac{(\text { nutrient consumed }- \text { nutrient in excreta) }}{\text { nutrient consumed }}\right] \times 100 \%
$$

Nutrients digestibility (protein and crude fiber) was estimated to support the performance; therefore, body weight was also determined at the end of the experiment (end of starter period) on 21-day old.

\section{Statistical Analysis}

Data were statistically analyzed using analysis of variance and continued to Duncan's multiple range test when the treatment indicated significant effect.

\section{RESULTS AND DISCUSSION}

Dietary synbiotic supplementation of both $L$. casei and inulin of dahlia tuber extract (LEDT, T1), and L. casei and garlic extract (LEGT, T2) significantly increased intestinal LAB population and reduced the amount of coliform of broiler chickens compared to control (Table 2). The increased LAB population can be correlated with the increase in the production of organic acids or short-chain fatty acids due to the bacterial fermentation effect on either dahlia tuber or garlic extracts containing prebiotic, which made the intestine to be acidic condition (lower $\mathrm{pH}$ ). This microenvironmental condition of the intestine causes the decrease in pathogenic bacteria (coliform) population in $\mathrm{T} 1$ and $\mathrm{T} 2$ treatments.

The results of this study were following Mountzouris et al. (2007) who stated that probiotic such as Lactobacillus sp. culture reduce the availability of nutrients or food for pathogenic bacteria and increase colonization of lactic acid bacteria. Rebole et al. (2010) reported that the addition of inulin from chicory root powder at a level of $10 \mathrm{~g} / \mathrm{kg}$ and $20 \mathrm{~g} / \mathrm{kg}$ in chicken rations were able to increase intestinal amount of Lactobacillus sp.

The increasing lactic acid bacteria (LAB) counts, in addition, to produce higher amount of lactic acid and short-chain fatty acids (SCFA); this beneficial bacteria was also known to produce harmful metabolites. Hydrogen peroxide, carbon dioxide $\left(\mathrm{CO}_{2}\right)$, and antimicrobial (bacteriocin) are the harmful metabolites that are antagonistic to the growth of pathogenic bacteria, and on the other side, improves growth of beneficial bacteria in the small intestine (Azhar, 2009). Other possible factor is that the decrease in the number of pathogenic bacterial colonization is caused by the lost ability of pathogenic bacteria in competing to use nutrients in the small intestine. Result of this study showed a significant increase in the number of colonization of LAB due to dietary addition of synbiotic of either $L$. casei + dahlia tuber extract/LEDT or $L$. casei garlic extract/LEGT (Table 2).

This result proved that both synbiotics were able to change intestinal microbes population and balance. L. casei function as a probiotic bacteria had a capability in modifying the digestive tract microenvironment of broilers and lead to the increased growth of nonpathogenic microbes, facultative anaerobic and grampositive bacteria that can produce lactic acid and hydrogen peroxide (Yang et al., 2009). Those toxic or harmful compounds produced by LAB suppressed the growth of intestinal pathogens as indicated by the decreased coliform counts found in the present study, as a response to dietary treatment with synbiotics supplementation. The present result was in accordance with the previous study (Mountzouris et al., 2007), that dietary addition of Lactobacillus sp. significantly reduced cecal coliform and Salmonella enteritidis populations, and also Clostridium perfringen number (Kizerwetter-Swida, 2009).

The increased intestinal LAB and the decreased E. coli counts was observed in starter period of crossbred native chickens 
given prebiotic inulin of dahlia tuber (Krismiyanto et al., 2014), and in broilers fed glucomannan extract of porang tuber (Perdinan et al., 2019), without any additional probiotic. The same result was also reported previously (Suthama et al., 2018) that the increased LAB population was found in soybean meal extract-fed broiler.

Probiotic, however, had been reported and well documented to be powerful and beneficial bacteria in supporting poultry production in the tropical country, such as Indonesia. For example, Cholis et al. (2018) reported that Lactobacillus sp., when added alone to the low protein diet without combination with prebiotic dramatically increased LAB and reduced coliform population and improved body weight. It can be postulated that the improved bacterial balance is in concomitant with the increased short-chain fatty acids, a fermentation product due to the biological activity of beneficial effects of LAB. In addition, Lactobacillus casei produced anti-microbial substances that can suppressed the growth of pathogenic bacteria (Sunaryanto et al., 2014).

Table 2. Effect of synbiotic on intestinal bacteria, nutrient digestibility and body weight of broiler chicken

\begin{tabular}{lccc}
\hline \multirow{2}{*}{ Parameter } & \multicolumn{3}{c}{ Treatment } \\
\cline { 2 - 4 } & Control (T0) & LEDT (T1) & LEGT (T2) \\
\hline LAB $\left(10^{9} \mathrm{cfu} / \mathrm{g}\right)$ & $5.02^{\mathrm{b}}$ & $5.21^{\mathrm{a}}$ & $5.20^{\mathrm{a}}$ \\
Coliform $\left(10^{6} \mathrm{cfu} / \mathrm{g}\right)$ & $4.24^{\mathrm{a}}$ & $3.54^{\mathrm{b}}$ & $3.65^{\mathrm{b}}$ \\
Protein Digestibility (\%) & $78.46^{\mathrm{b}}$ & $81.03^{\mathrm{a}}$ & $78.50^{\mathrm{b}}$ \\
Crude fiber digestibility (\%) & $24.41^{\mathrm{b}}$ & $27.68^{\mathrm{a}}$ & $27.01^{\mathrm{a}}$ \\
Body weight (g) & $602.39^{\mathrm{b}}$ & $623.5^{\mathrm{a}}$ & $633.46^{\mathrm{a}}$ \\
\hline
\end{tabular}

${ }^{a-b}$ Different superscript within the same row indicate significant difference $(P<0.05)$

\section{Nutrient Digestibility}

Synbiotics composed of $L$. casei and dahlia tuber extract, as well as $L$. case $i$ and garlic extract improved digestion process, based on protein and crude fiber digestibility. The increased nutrients digestibility was closely related to the improvement of intestinal microbes balance as indicated by higher LAB and lower $E$. coli populations (Table 2) which supports the healthy intestinal tract.

It was reported elsewhere that healthy intestinal tract facilitates the maximal digestive enzyme activity and bring about digestibility improvement. The present result was supported by Afriyati et al. (2019) that dietary addition of Lactobacillus sp. as a probiotic at the level of $1.2 \mathrm{ml}$ in broiler chicken-increased crude fiber digestibility by $24.35 \%$ as compared to control group (24.99 vs. 20.97\%). The increased digestibility of crude fiber in $\mathrm{T} 1$ and $\mathrm{T} 2$ (Table 2) provided a positive impact on the improved protein digestibility. It is well known that crude fiber act a negative effect on nutrient digestibility and availability, in this case, protein, when it could not be digested more due to its nutritional binding characteristic properties.

Dietary addition of synbiotics LEDT (T1) and LEGT (T2) were able to change the condition of the digestive tract leading to the improved digestion process. Phenomenon of the present study can be described that inulin from dahlia tuber and garlic extracts provided a substrate and function as "feed source" for the development of L. casei in particular, and LAB in general.

\section{Bodyweight}

Increased bodyweight of chickens in $\mathrm{T} 1$ and $\mathrm{T} 2$ treatments was thought to be due to the role of the synbiotic in improving the intestinal microbes balance that has been discussed in the previous parameter. The improved bacterial balance can be correlated with the higher intestinal healthy and thus better nutrients digestibility, especially protein, can be resulted (Table 2). The 
higher protein digestibility serve as the important substrate for body protein synthesis that contributes to the increased body weight. The livability of probiotic bacteria increase when combined with prebiotic, called as synbiotic, because specific substrates as its "feed/nutrition source" is available for fermentation, and in turn, animal gets more advantages from the feeding a combination of probiotics and prebiotics. It has been previously described that some species also produce hydrogen peroxide, which inhibits the growth of gramnegative bacteria.

Healthy digestive tract condition impacts on better digestion process and increased nutrients availability, especially protein, for meat protein synthesis, and lead to the increase in body weight. Synbiotic administration has been proven to be effective in increasing the growth of broilers (Abdel-Raheem et al., 2012). The results of the present study were supported by Awad et al. (2009).

Broilers fed synbiotic with bacterial concentration of $5 \times 108 \mathrm{cfu} / \mathrm{ml}$ was better than those given probiotics alone. It was reported that synbiotic increased the percentage of carcass weight and body weight gain by $66.77 \%$ and $51.61 \mathrm{~g} / \mathrm{day}$, respectively, and were higher than those observed with probiotic alone namely, $59.54 \%$ and $49.28 \mathrm{~g} /$ day, respectively. It has been previously described that the addition of symbiotic either LEDT (T1) or LEGT (T2) indirectly increased nutrients utilization efficiency, protein in particular, indicated by protein digestibility (Table 2 ) due to the improved intestinal health condition.

The increase in protein availability is important factor for body tissue synthesis which is finally improve body weight. Improvement of intestinal morphology indicated by better villi growth in native chickens given Lactobacillus sp. combined with prebiotic inulin increased protein digestibility and provided a positive impact in promoting body weight (Purbarani et al. 2019).

\section{CONCLUSION}

The conclusion is that dietary addition of $2 \%$ synbiotic LEDT (T1), a combination of Lactobacillus casei and $2 \%$ extract of dahlia tuber, results the best performance of broiler chickens through the improved intestinal microbiota and protein digestibility.

\section{ACKNOWLEDGMENTS}

The authors would like to express grateful thank to Institute for Research and Community Service, Diponegoro University, through the "Program Riset Pengembangan dan Penerapan (RPP)" due to the valuable funding contribution with the contract number 385-41 / UN7.P4.3 / PP / 2019.

\section{REFERENCES}

AbdelRaheem, S., AbdAllah, S., \& Hassanein, K. (2012). The effects of prebiotic, probiotic and synbiotic supplementation on intestinal microbial ecology and histomorphology of broiler chickens. International Journal for Agro Veterinary and Medical Sciences, 6(4), 277-289. https://doi.org/10.5455 /ijavms. 156

Abdurrahman, Z. H., Pramono, Y. B., \& Suthama, N. (2016a). Feeding effect of inulin derived from dahlia tuber combined with Lactobacillus sp. on meat protein mass of crossbred kampong chicken. Journal of the Indonesian Tropical Animal Agriculture, 41(1), 37-44. https://doi. org/10.14710/jitaa.41.1.37-44

Abdurrahman, Z. H., Pramono, Y. B., \& Suthama, N. (2016b). Meat characteristic of crossbred local chicken fed inulin of dahlia tuber and Lactobacillus sp. Media Peternakan, 39(2), 112-118. https://doi.org/10.53 98/medpet.2016.39.2.112

Adil, S., \& Magray, S. N. (2012). Impact and Manipulation of gut microflora in poultry: a review. Journal of Animal and Veterinary Advances, 11(6), 873- 
877. https://doi.org/10.3923/javaa.20 12.873 .877

Afriyanti, R., Mangisah, I., \& Yunianto, V. D. (2019). Nilai kecernaan nutrien broiler akibat penambahan Lactobacillus sp. dalam ransum yang mengandung mikropartikel tepung cangkang telur. Jurnal Sain Peternakan Indonesia, 14(2), 215221. https://doi.org/10.31186/jspi.id. 14.2.215-221

Alakomi, H.-L., Skyttä, E., Saarela, M., Mattila-Sandholm, T., Latva-Kala, K., \& Helander, I. M. (2000). Lactic acid permeabilizes gram-negative bacteria by disrupting the outer membrane. Applied and Environmental Microbiology, 66(5), 2001-2005. https://doi.org/10.1128/AEM.66.5.20 01-2005.2000

Awad, W. A., Ghareeb, K., Abdel-Raheem, S., \& Böhm, J. (2009). Effects of dietary inclusion of probiotic and synbiotic on growth performance, organ weights, and intestinal histomorphology of broiler chickens. Poultry Science, 88(1), 49-56. https:// doi.org/10.3382/ps.2008-00244

Azhar, M. (2009). Inulin sebagai Prebioik (12th ed.). Sainstek.

Bolton, W. (1967). MAFF Bulletin (174th ed.). London: Poultry Nutrition.

Cholis, M. A., Suthama, N., \& Sukamto, B. (2018). Feeding microparticle protein diet combined with Lactobacillus $s p$. on existence of intestinal bacteria and growth of broiler chickens. Journal of the Indonesian Tropical Animal Agriculture, 43(3), 265-271. https:// doi.org/10.14710/jitaa.43.3.265-271

Fajrih, N., Suthama, N., \& Yunianto, V. D. (2014). Body resistance and productive performances of crossbred local chicken fed inulin of dahlia tubers. Media Peternakan, 37(2), 108-114. https://doi.org/10.5398/med pet.2014.37.2.108

Fanani, A. F., Suthama, N., \& Sukamto, B. (2016). Effect of dahlia tuber supplementation as inulin source on protein digestibility and productivity of crossbred local chicken. Indonesian Journal of Veterinary Sciences, 10(1). https://doi.org/10.21157/j.ked.hewan. v10i1.3372

Faradila, S., Suthama, N., \& Sukamto, B. (2016). Combination inulin of dahlia variabilis tubers-Lactobacillus $s p$ optimizing the development of intestinal micro. Jurnal Veteriner, 17(2), 168-175. https://doi.org/10.19 087/jveteriner.2016.17.2.168

Hartono, Muthiadin, C., \& Bakri, Z. (2012). Daya hambat sinbiotik ekstrak inulin bawang merah (Allium cepa L .) dengan bakteri Lactobacillus acidophilus terhadap pertumbuhan bakteri Escherichia coli. Jurnal Bionature, 13(1), 31-41.

Huyghebaert, G., Ducatelle, R., \& Immerseel, F. Van. (2011). An update on alternatives to antimicrobial growth promoters for broilers. The Veterinary Journal, 187(2), 182-188. https://doi.org/10.1016/j.tvj1.2010.03. 003

Kizerwetter-Świda, M., \& Binek, M. (2009). Protective effect of potentially probiotic Lactobacillus strain on infection with pathogenic bacteria in chickens. Polish Journal of Veterinary Sciences, 12(1), 15-20.

Kong, C., \& Adeola, O. (2014). Evaluation of amino acid and energy utilization in feedstuff for swine and poultry diets. Asian-Australasian Journal of Animal Sciences, 27(7), 917-925. https://doi. org/10.5713/ajas.2014.r.02

Krismiyanto, L., Suthama, N., \& Wahyuni, H. I. (2014). Feeding effect of inulin derived from dahlia variabilis tuber on intestinal microbes in starter period of crossbred native chickens. Journal of the Indonesian Tropical Animal Agriculture, 39(4), 217-223. https:// doi.org/10.14710/jitaa.39.4.217-223

Meluzzi, A., Sirri, F., Tallarico, N., \& Franchini, A. (2001). Nitrogen retention and performance of brown laying hens on diets with different 
protein content and constant concentration of amino acids and energy. British Poultry Science, 42(2), 213-217. https://doi.org/10.1080/000 71660120048474

Mountzouris, K. C., Tsirtsikos, P., Kalamara, E., Nitsch, S., Schatzmayr, G., \& Fegeros, K. (2007). Evaluation of the efficacy of a probiotic containing Lactobacillus, Bifidobacterium, Enterococcus, and Pediococcus Strains in promoting broiler performance and modulating cecal microflora composition and metabolic activities. Poultry Science, 86(2), 309-317. https://doi.org/10.10 93/ps/86.2.309

Ngatirah, \& Ulfah, M. (2009). Suplementasi prebiotik dari tanaman lokal pada media pertumbuhan Lactobacillus dad 13. Jurnal Teknologi Dan Enjiniring Pertanian, 4(1), 29-33.

Perdinan, A., Wahyuni, H. I., \& Suthama, N. (2019). Body resistance and growth performance of broiler fed glucomannan extracted from amorphophallus onchophyllus tuber. Tropical Animal Science Journal, 42(1), 33-38. https://doi.org/10.5398/ tasj.2019.42.1.33

Purbarani, S. A., Wahyuni, H. I., \& Suthama, N. (2019). Dahlia inulin and Lactobacillus sp. in step down protein diet on villi development and growth of KUB Chickens. Tropical Animal Science Journal, 42(1), 19-24. https:// doi.org/10.5398/tasj.2019.42.1.19
Sunaryanto, R., Martius, E., \& Marwoto, B. (2014). Uji kemampuan Lactobacillus casei sebagai agensia probiotik. Jurnal Bioteknologi \& Biosains Indonesia (JBBI), 1(1), 9-14. https:// doi.org/10.29122/jbbi.v1i1.546

Sundari, E., Desfitri, E. R., Martynis, M., \& Praputri, E. (2014). Identifikasi dan kondisi ekstraksi inulin dari umbi dahlia di Sumatera Barat. In Prosiding SNSTL I.

Suthama, N., Pramono, Y. B., \& Sukamto, B. (2018). Improvement of broiler meat quality due to dietary inclusion of soybean oligosaccharide derived from soybean meal extract. IOP Conference Series: Earth and Environmental Science, 102, 012009. https://doi.org/10.1088/1755-1315/10 2/1/012009

Wulandari, L. T., Suthama, N., \& Sukamto, B. (2018). Blood parameters and productivity of broilers fed ration composed of microparticle protein with the addition of Lactobacillus sp. Journal of the Indonesian Tropical Animal Agriculture, 43(4), 396-404. https://doi.org/10.14710/jitaa.43.4.396 $-404$

Yang, Y., Iji, P. A., \& Choct, M. (2009). Dietary modulation of gut microflora in broiler chickens: a review of the role of six kinds of alternatives to in-feed antibiotics. World's Poultry Science Journal, 65(1), 97-114. https://doi. org/10.1017/S0043933909000087 